\title{
MODERN BREEDING APPROACHES FOR DURABLE RESISTANCE AGAINST THE PARASITIC PLANT STRIGA
}

\author{
Steven Runo \\ Department of Biochemistry, Microbiology and Biotechnology, Kenyatta University, Kenya \\ Crop losses caused by parasitic plants of the genus Striga pose a great danger to the livelihoods of \\ millions of smallholder farmers in Africa. The parasite attaches to host crops and siphons nutrients \\ leading to severe retardation and crop death. Controlling Striga is difficult because of the parasite's \\ ability to produce large amounts of seeds that can remain dormant in the soil for decades - only \\ germinating in response to chemical cues (strigolactones) from the host. In recent years, breeding \\ crops for host-based resistance has been prioritized. However, such programs have not taken into \\ account Striga's ability to overcome host resistance. As a result, introduced resistance fails because \\ of increased Striga virulence (infection severity). This article reviews technologies for a new paradigm \\ in Striga resistance breeding that incorporates host resistance breeding with well-informed know- \\ ledge of parasite resistance in order to ensure durability of resistance.
}

KEY WORDS: STRIGA, HOST BASED RESISTANCE, GENOME WIDE ASSOCIATION MAPPING, RNA SEQUENCING

\section{Introduction}

One of the greatest challenges to staple cereal production in Africa is the parasitic plant Striga that kills crops by attaching to their roots and siphoning nutrients. The Striga genus has over thirty species distributed over 50 countries in Sub-Saharan Africa (SSA), causing an estimated 7 billion dollars' worth of crop losses every year (Ejeta, 2007). Of the many Striga species, S. hermonthica, S. asiatica - both parasitic to cereal crops - and S. gesneriodes specific to cowpea - are the deadliest. It is difficult to control Striga because of its ability to produce extremely large numbers of seeds - as each Striga flower spike can produce over 50,000 seeds (Yoder and Scholes, 2010). These seeds can remain viable in the soil for up to I4 years, and germinate only in reaction to chemical cues given by the host plant's root exudates (Bouwmeester et al., 2007).

Desperate to suppress Striga infestations, smallholder farmers in Africa have battled the plant using cultural and agronomic practices such as hand-weeding, crop rotation (Kanampiu et al., 2018), use of resistant crops that do not allow Striga to attach (Cissoko et al., 20II) use of tolerant crops that withstand Striga attachment with no yield reduction, and use of 'trap crops' to encourage parasite germination on incompatible hosts (Midega et al., 2010). Although these methods have been extensively encouraged over the years, crop losses and the host range of these parasites have continued to increase. 
Low success rates in achieving significant Striga management has led to extensive searches for cultivars and wild relatives of sorghum that are resistant to the parasite (Mbuvi et al., 20I7; Mutinda et al., 20I8; Rich et al., 2004). These resistant varieties have been introduced in some breeding programs in SSA (Ngugi et al., 20r6). Still, the resistance is often weak and sometimes breaks down due to the appearance of new Striga ecotypes (Botanga and Timko, 2007).

Resistance breakdown in most host-pathogen interactions occurs when a pathogen manages to avoid the host defense surveillance mechanism. This arms race (host resistance versus pathogen virulence) is described well in the 'zigzag' model first proposed by Florr, (I97I). In this two-level defense model, Patterns Triggered Immunity (PTI) is first induced by the perception of different Pathogen Activated Molecular Patterns (PAMPs) followed by Effector Triggered Immunity (ETI), that is induced in response to pathogen factors - effectors (Alfano \& Collmer, 2004).

To avoid the activation of the host immune response - and consequently resistance breakdown, the parasite rapidly changes its PAMPs as well as effectors. This phenomenon has been well documented in plant-microbe interactions. For example, (Van de Wouw et al., 20Io) describe the breakdown of the Rlmi gene that confers resistance against blackleg fungus, Leptosphaeria maculans in Brassica napus (canola) due to evolution of the avirulence gene, AvrLmi, in fungal populations.

Although never described for Striga, increasing evidence points to a possible role of pathogen effectors in race specific interactions of S. gesneriodes. In the aforementioned report, the authors cloned a gene-for-gene Striga resistance gene (RSG3-30I) which has a coiledcoil nucleotide binding site leucine-rich repeat domain (Li and Timko, 2009). Resistance as a result of the gene is only activated by a specific hypervirulent $\mathrm{S}$. gesneriodes race $\mathrm{SG}_{3}$ from Niger (Timko et al., 20I2), pointing to the possibility of avirulence gene action. Evidence for possible involvement of effectors in Striga-host interactions underscore the importance of developing new paradigms in breeding against Striga that take into account virulence and host-pathogen specificity.

\section{Exploiting host resistance as a control strategy against Striga}

Host based resistance provides an attractive breeding strategy because it is cost effective and sustainable. Previous research has shown that sorghum is an attractive source for resistance against $S$. hermonthica and S. asiatica compared to limited sources of resistance from maize (Mutinda et al., 20I8), rice (Cissoko et al., 20II; Gurney et al., 2006) and their wild relatives (Amusan et al., 2008). Such resistance is evident in Striga infested fields where if maize and sorghum are grown side by side, maize is more adversely affected by the parasite (Figure I). Sorghum's high capacity for Striga resistance can be explained by the fact that it co-evolved with Striga in northeastern Africa. This region which harbors the greatest diversity of both wild and cultivated sorghum (Paterson, 2008), is also the natural range of the Striga parasite (Musselman and Hepper, I986).

Striga resistance can either act before (pre-attachment resistance) or after infection (postgermination resistance). Some host crops do not induce Striga to germinate because the 
hosts do not produce sufficient amounts of Striga germination stimulants - called Strigolactones, or because Striga receptors that perceive germination stimulants are insensitive to the strigolactone produced by the host. These hosts demonstrate what is known as pre-germination resistance and are referred to as low germination stimulant (LGS) varieties (Jamil et al., 20II).

For example, some sorghum varieties have the LOW GERMINATION STIMULANT (LGS) trait and these have been exploited as a control strategy against Striga (Hess and Ejeta, 1992). The genetic cause of this resistance has recently been found to be due to a natural mutation in the LGS loci of sorghum (Gobena et al., 2017). Plausibly, many more varieties of sorghum habouring a mutation on the LGS loci exist but have not been identified. The vast genetic diversity of sorghum globally as well as the explosion of sequencing technology now allows screening and identification of such mutations.

An effective strategy to perform such screening and identification is genome wide association (GWAS) mapping. In this strategy, a large number of diverse individuals, or a mapping population is genotyped with high resolution genetic markers. This is followed by an analysis of the desired trait (phenotype). Subsequently, genotype and phenotype are correlated to determine association of the trait with particular genetic loci - identifiable by a genetic marker. With regard to pre-germination resistance against Striga, it is possible to measure trait data by determining the frequency of sorghum's resistance to stimulating Striga seed germination. Further pre-germination resistance data can be obtained by analysis of the amounts and types of strigolatones present in root exudate. In addition to the low stimulation of Striga germination, some Striga hosts exhibit postattachment Striga resistance mechanisms that act after Striga attachment and attempted penetration into host. These mechanisms result in physiological or biochemical barriers, which prevent the Striga haustorium from connecting to the host xylem (Maiti et al., I984). Host plants can also produce secondary metabolites that block parasite ingression (Mbuvi et al., 20I7) or induce a hypersensitive immune response at the host-parasite interphase (Mohamed et al., 2003). In yet other instances, Striga produces enzymes that degrade host tissues (Rogers and Nelson, 1962).

This resistance has been described as quantitatively inherited (Haussmann et al., 2004). In line with this assertion, Striga resistance quantitative trail loci (QTL) has been identified in sorghum (Haussmann et al., 2004) and rice (Swarbrick et al., 2009) in a Recombinant Inbred Line (RIL) population that was derived from a cross between the resistant cultivar Ni3 and a susceptible cultivar E36-I (Haussmann et al., 2004). Such QTLs have been further utilised in breeding programs in Africa (Masiga et al., 20I4; Yohannes et al., 2015).

The biological and genetic mechanisms underpinning this form of resistance in Striga are not yet understood but it is reasonable to assume that the effect is a result of multiple genes acting to fortify the host against invasion by the parasite. It is also possible that Striga resistance may be acting qualitatively in a gene-for-gene resistance mechanism as was described in the case of S. gesneriodes (Li and Timko, 2009). Both of these forms of resistance can be identified using GWAS. To achieve this, sorghum accessions/mapping 
populations can be evaluated for Striga resistance using a high throughput Striga resistance screening strategy such as the one based on rhizotrons (Mbuvi et al., 20I7). In this resistance screening strategy, transparent root observation chambers are used to assay host root development and infection by Striga. Resistance is scored after 2I days for metrics of: number, size and biomass of Striga attached on host roots. Sorghum accessions can then be genotyped and associated loci can be used in Striga resistance breeding programs.

In addition to GWAS, resistance genes can be identified using RNA sequencing to determine genes - in resistant sorghum - that are differentially expressed upon Striga infection. This approach can help pinpoint resistance (R) genes activated by Striga infection. Ideally, RNA sequencing to obtain resistance genes should be performed on germplasm that has been screened and found to be Striga resistant.

The plethora of genes identified will help in development of 'an arsenal' of resistance genes for deployment into susceptible varieties using modern breeding approaches. To ensure that Striga does not overcome resistance, multiple genes can be combined together and introduced into crop varieties popular to farmers.

\section{Preventing Striga from overcoming host resistance}

Even with good resistance sources, it is possible that Striga can overcome resistance because of rapidly evolving pathogen virulence. It is logical to assume that Striga can with time - acquire the ability to breach a host's defenses through suppression of plant immunity and promotion of pathogenesis by injecting effectors into plant cells. Such a hypothesis is supported by work on other host-pathogen interactions where it has been shown that secreted effectors can suppress both PTI immunity and ETI protein-activated immunity (Alfano and Collmer, 2004).

Plausibly, Striga virulence genes undergo rapid adaptive diversification in order to acquire new host specificities as has been described in other pathogens (Li et al., 2009; Meyers et al., I998). Such evolution is accelerated by Striga's high genetic diversity; high outcrossing rates; dormancy and multiple hosts. The concept of fast evolving virulence in Striga is supported by the striking variations in the virulence profiles of different S. hermonthica populations (Mbuvi et al., 2017). Although not documented, it is also likely that such variations occur among individuals of S. hermonthica isolated from different host sources (because different hosts have varying susceptibilities and therefore varying selection pressure), and from seeds deposited in different seasons or years (because varying environmental stressors impose different selection pressures over time).

Therefore, the S. hermonthica in soil is highly heterogenous with expected variations in virulence and host specificity and, to avoid resistance breakdown, future breeding programs should take into account the vast Striga genetic diversity. Such work should seek to genotype Striga from different eco-geographical regions and identify fingerprints unique to these regions. Subsequently, the specificity of Striga ecotypes and virulence can be linked with genetic markers. This data will in turn inform on which crop variety is appropriate for which region, thereby preventing Striga from overcoming host resistance. 
Such knowledge can also be used as a baseline for future reference when establishing the evolution patterns and rates. Certainly, interactions between S. hermonthica and the environment - including the physical and biological properties of soil as well as the microbiome can lead to variations in Striga's ability to infect a host and should be areas of future investigation.

\section{Summary and perspectives}

Today, the explosion of new information coming from fully sequenced genomes, as well as Striga sequencing initiatives, plus high throughput tools for transcriptome analysis, provide a means to complement the more traditional approaches of Striga management. However, to achieve meaningful success in Striga management, it is critical to integrate good agricultural practices with other Striga management strategies.

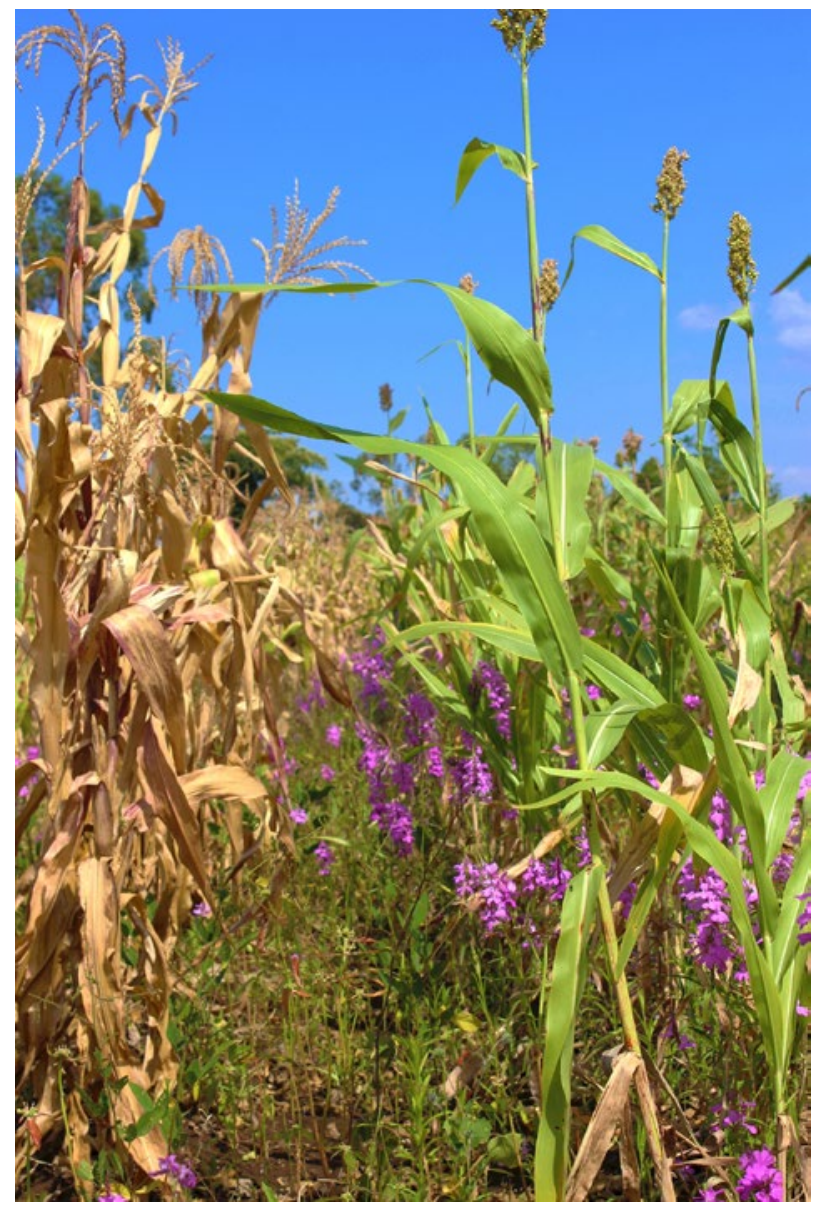

Figure 1: Sorghum is a good source of natural resistance against Striga hermonthica. Maize (left) is more adversely affected by parasite compared to the sorghum (right). 


\section{References}

Alfano, J. R., and Collmer, A. (2004). Type III secretion system effector proteins: Double agents in bacterial disease and plant defense. http:|/dx.doi.org/10.1146/annurev.phyto.42.040103.110731 42, 385-4I4. doi:Io.II46/annurev.phyto.42.040103.II073I.

Amusan, I. O., Rich, P. J., Menkir, A., Housley, T., and Ejeta, G. (2008). Resistance to Striga hermonthica in a maize inbred line derived from Zea diploperennis. New Phytologist I78, I57-I66. doi:Io.IIII/ j.I469-8I37.2007.02355.x.

Botanga, C. J. and Timko, M. P. (2007). Phenetic relationships among different races of Striga gesnerioides (Willd.) Vatke from West Africa. Genome 49, I35I-I365. doi:Io.II39/go6-086.

Bouwmeester, H. J., Roux, C., Lopez-Raez, J. A., and Bécard, G. (2007). Rhizosphere communication of plants, parasitic plants and AM fungi. Trends in plant science I2, 224-230. doi:10.1016/j. tplants.2007.03.009.

Cissoko, M., Boisnard, A., Rodenburg, J., Press, M. C., and Scholes, J. D. (20II). New Rice for Africa (NERICA) cultivars exhibit different levels of post-attachment resistance against the parasitic weeds Striga hermonthica and Striga asiatica. New Phytologist I92, 952-963. doi:Io.InI/j.I4698137.2011.03846.x.

Ejeta, G. (2007). "The Striga scourge in Africa: a growing pandemic," in Integrating New Technologies for Striga Control, eds.G. Ejeta and J. Gressel (Singapore: World Scientific Publishing Company), 3-16.

Gobena, D., Shimels, M., Rich, P. J., Ruyter-Spira, C., Bouwmeester, H., Kanuganti, S., et al. (2017). Mutation in sorghum LOW GERMINATION STIMULANT Ialters strigolactones and causes Striga resistance. PNAS II4, 447I-4476. doi:Io.I073/pnas.I6I8965II4.

Gurney, A. L., Slate, J., Press, M. C., and Scholes, J. D. (2006). A novel form of resistance in rice to the angiosperm parasite Striga hermonthica. New Phytologist I69, I99-208. doi:Io.III/j.I4698137.2005.01560.x.

Haussmann, B. I. G., Hess, D. E., Omanya, G. O., Folkertsma, R. T., Reddy, B. V. S., Kayentao, M., et al. (2004). Genomic regions influencing resistance to the parasitic weed Striga hermonthica in two recombinant inbred populations of sorghum. Theor Appl Genet I09, 1005-I0I6. doi:10.1007/ soor22-004-1706-9.

Hess, D. E., and Ejeta, G. (1992). Inheritance of Resistance to Striga in Sorghum Genotype SRN39. Plant Breeding I09, 233-24I. doi:I0.IIII/j.I439-0523.1992.tboor78.x.

Jamil, M., Rodenburg, J., Charnikhova, T., and Bouwmeester, H. J. (20II). Pre-attachment Striga hermonthica resistance of New Rice for Africa (NERICA) cultivars based on low strigolactone production. New Phytologist 192, 964-975. doi:I0.IIII/j.I469-8137.2011.03850.x.

Kanampiu, F., Makumbi, D., Mageto, E., Omanya, G., Waruingi, S., Musyoka, P., et al. (2018). Assessment of management options on Striga infestation and maize grain yield in Kenya. Weed Science 66, 516-524. doi:10.1017/wsc.2018.4.

Li, J., and Timko, M. P. (2009). Gene-for-Gene resistance in Striga-cowpea associations. Science 325, I094-I094. doi:Io.II26/science.II74754.

Li, J., Lis, K. E., and Timko, M. P. (2009). Molecular genetics of race-specific resistance of cowpea to Striga gesnerioides (Willd.). Pest Management Science 65, 520-527. doi:I0.1002/ps.1722.

Maiti, R. K., Ramaiah, K. V., Bisen, S. S., and CHIDLEY, V. L. (1984). A Comparative Study of the Haustorial Development of Striga asiatica (L.) Kuntze on Sorghum Cultivars. Ann Bot 54, 447-457.

Masiga, C. W., Mugoya, C., Ali, R., Mohamed, A., Osama, S., Ngugi, A., et al. (2014). "Enhanced utilization of biotechnology research and development innovations in eastern and central Africa for agro-ecological intensification," in Challenges and Opportunities for Agricultural Intensification of the Humid Highland Systems of Sub-Saharan Africa (Cham: Springer International Publishing), 97-IO4. doi:I0.1007/978-3-319-07662-I_8.

Mbuvi, D. A., Masiga, C. W., Kuria, E., Masanga, J., Wamalwa, M., Mohamed, A., et al. (2017). Novel sources of witchweed (Striga) resistance from wild sorghum accessions. Frontiers in Plant Science 8, 27I. doi:10.338g/fpls.2017.001r6. 
Meyers, B. C., Shen, K. A., Rohani, P., Gaut, B. S., and Michelmore, R. W. (1998). Receptor-like genes in the major resistance locus of lettuce are subject to divergent selection. Plant Cell Io, I833-1846. doi:IO.IIO5/tpc.IO.II.I833.

Midega, C. A. O., Khan, Z. R., Amudavi, D. M., Pittchar, J., and Pickett, J. A. (20I0). Integrated management of Striga hermonthica and cereal stemborers in finger millet (Eleusine coracana (L.) Gaertn.) through intercropping with Desmodium intortum. International Journal of Pest Management. doi:Io.1080/ttpm20.v056.io2;page:string:Article/Chapter.

Mohamed, A., Ellicott, A., Housley, T. L., and Ejeta, G. (2003). Hypersensitive response to Striga infection in sorgum. Crop Science 43, I320-1324. doi:I0.2135/cropsci2003.1320.

Musselman, L. J., and Hepper, F. N. (I986). The Witchweeds (Striga, Scrophulariaceae) of the Sudan Republic. Kew Bulletin 4I, 205. doi:10.2307/4103043.

Mutinda, S. M., Masanga, J., Mutuku, J. M., Runo, S., and Alakonya, A. (20I8). KSTP 94, an Openpollinated maize variety has post-attachment resistance to purple witchweed (Striga hermonthica). Weed Science 66, 525-529. doi:10.1017/wsc.2018.24.

Ngugi, K., Ngugi, A. J., Osama, S., and Mugoya, C. (2016). Combating striga weed in sorghum by transferring resistance quantitative trait loci through molecular marker assisted introgression. Journal of Plant Breeding and Genetics 3, 67-76.

Paterson, A. H. (2008). Genomics of Sorghum. International Journal of Plant Genomics 2008, I-6. doi:I0.II55/2008/36245I.

Rich, P. J., Grenier, C., and Ejeta, G. (2004). Striga resistance in the wild relatives of sorghum. Crop Science 44, 2221-2229. doi:I0.2135/cropsci2004.222I.

Rogers, W. E., and Nelson, R. R. (I962). Penetration and nutrition of Striga asiatica. Phytopathology.

Swarbrick, P. J., Scholes, J. D., Press, M. C., and Slate, J. (2009). A major QTL for resistance of rice to the parasitic plant Striga hermonthica is not dependent on genetic background. Pest Management Science 65, 528-532. doi:10.1002/ps.I719.

Timko, M. P., Huang, K., and Lis, K. E. (2012). Host resistance and parasite virulence in Striga-host plant interactions: A shifting balance of power. Weed Science $160,307-315$. doi:I0.I6I4/WS-D-II00039.I.

Van de Wouw, A. P., Cozijnsen, A. J., Hane, J. K., Brunner, P. C., McDonald, B. A., Oliver, R. P., et al. (2010). Evolution of linked avirulence effectors in Leptosphaeria maculans is affected by genomic environment and exposure to resistance genes in host plants. PLOS Pathogens 6, eIoorr8o. doi:I0.I37I/journal.ppat.I0oIr80.

Yoder, J. I., and Scholes, J. D. (2010). Host plant resistance to parasitic weeds; recent progress and bottlenecks. Current Opinion in Plant Biology I3, 478-484. doi:Io.1or6/j.pbi.2010.04.oII.

Yohannes, T., Abraha, T., Kiambi, D., Folkertsma, R., Tom Hash, C., Ngugi, K., et al. (2015). Markerassisted introgression improves Striga resistance in an Eritrean farmer-preferred sorghum variety. Field Crops Research I73, 22-29. doi:I0.I0I6/j.fcr.2014.12.008. 